\title{
ЯЗЫКОЗНАНИЕ
}

Copyright (C) 2018 by the Kalmyk Scientific Center of the Russian Academy of Sciences

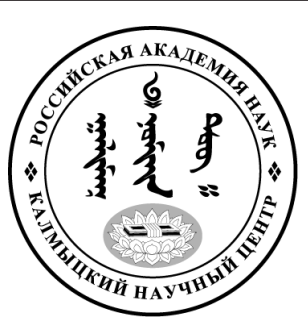

Published in the Russian Federation

Oriental Studies (Previous Name: Bulletin of the Kalmyk Institute for

Humanities of the Russian Academy of Sciences)

Has been issued as a journal since 2008

ISSN: 2619-0990; E-ISSN: 2619-1008

Vol. 39, Is. 5, pp. 110-119, 2018

DOI 10.22162/2619-0990-2018-39-5-110-119

Journal homepage: https://kigiran.elpub.ru

УДК 81.373 .423

\section{К изучению омонимии калмыцкого языка и проблеме составления словаря омонимов}

Вячеслав Николаевич Хонинов ${ }^{1}$

${ }^{1}$ кандидат филологических наук, научный сотрудник, Институт языкознания РАН (125009, Россия, г. Москва, Б. Кисловский пер. д. 1, стр. 1). ORCID: 0000-0001-8461-6213. E-mail: altngasn@rambler.ru

\begin{abstract}
Аннотация
В работе дается краткий обзор истории изучения омонимов калмыцкого языка, определяются критерии разграничения омонимов и многозначных слов, описываются лексико-семантические связи между различными вариантами одного или разных слов, а также рассматривается грамматическая и словообразовательная омонимия. Базой для исследования послужил материал, собранный сплошной выборкой омонимов из калмыцко-русского словаря под редакцией Б. Д. Муниева и картотеки, составленной путем выборки фактического материала из произведений художественной литературы, устного народного творчества и периодической печати. В работе проведен качественный и количественный анализ пар лексем современного калмыцкого языка с разнообразными омонимичными связями, что позволило выявить типы и виды омонимии. Проведенный нами анализ показал, что в калмыцком языке омонимы образуются в результате разнообразных преобразований лексем. Возникают группы лексем с омонимичной формой, внутрисловные и межсловные связи которых поддаются разграничению лишь в языковом контексте. Данная работа является попыткой комплексного анализа способов формирования омонимов калмыцкого литературного языка, в которой приводятся сведения о типах и видах омонимов, затрагивается вопрос о создании «Словаря омонимов калмыцкого языка», рассматриваются проблемы и перспективы изучения омонимии калмыцкого литературного языка.
\end{abstract}

Ключевые слова: калмыцкий язык, лексика, омонимы, лексические омонимы, этимологические омонимы, семантическое значение, полисемия, омоформы 
Вопросы омонимии в связи с разработкой проблемы слова и его границ всегда привлекают к себе внимание ученых-языковедов. Актуальность исследования объясняется тем, что в калмыцком языкознании до сих пор остаются малоизученными многие проблемы лексикологии. Одна из них относится к омонимам. Настоящая статья посвящена комплексному анализу явления омонимии в современном калмыцком языке. Некоторые аспекты изучения явления омонимии были освещены в работах ряда авторов [Бардаев 1981; 1985; Бертагаев 1974; Виноградов 1977; Дарваев 2002; Колесников 1995; Логачева 2008; Малаховский 1990; Павлов 1969; и др.]. В этих исследованиях, в частности, дается определение омонимов, раскрываются в общих чертах способы их возникновения, критерии разграничения омонимии и многозначности, приводятся сведения о типах и видах омонимов, о роли омонимов в калмыцком языке.

Так, Э. Ч. Бардаев, описывая лексический состав калмыцкого литературного языка, различает три типа омонимов: лексические омонимы, грамматические омонимы и фонетические омонимы. К первой группе омонимов он относит собственно омонимы, примеры: хурһн 'палец' - хурһн 'ягненок', Yсн 'молоко' - Yсн 'волосы', ач 'заслуга' - $а ч$ 'внук'. Ученый также отмечает, что встречаются омонимичные ряды из трех и более единиц, например: иар 'вол' - иар 'парша' - цар 'жернов', үлгүр 'пословицы, поговорки' - үлгүр 'пример' - үлгүр 'выкройка', ки 'газ' - ки 'гриб' - ки 'мимо'. К грамматическим омонимам автор относит омоформы и приводит следующие примеры: hap 'рука' (сущ.) - hap 'выйди' (глаг. повел. накл.), ке 'нарядный' (прил.) - ке 'делай' (глаг.), улм 'болото' (сущ.) - улм 'еще пуще' (нар.), чи 'ты' (мест.) - чи 'вишня' (сущ.).

Фонетическими омонимами ученый называет омофоны, при которых слова произносятся одинаково, но различны на письме, например, ещз 'каприза' - еңзг 'ковш', сөң 'тост' - сөңзг 'один из пары' [Бардаев 1981: 8].

Отдельные замечания об омонимах встречаются в работе «Современная монгольская терминология» крупного монголиста Г. Ц. Пюрбеева. Он отмечает, что не все способы образования омонимов, известные в лексике, действуют в терминологии монгольского языка. Словообразовательная омонимия широко используется в терминологии, и притом «один и тот же термин может входить в разные терминологии данного языка»: үе: 1) анат. 'сустав', 2) этн. 'поколение', 3) лингв. - 'слог', 4) ист. и геол. - 'эпоха' [Пюрбеев 1984: 10]. Распад полисемантического слова также является одним из способов образования терминовомонимов, например: бүс 1) 'пояс, кушак'; 2) 'пояс земной'; 3) 'зона; пояс климатический'; 4) 'пояс в доменной печи'; хайлуулах бүс 'плавильный пояс' [Пюрбеев 1984: 46]. Метафорическое употребление слов приводит к образованию омонимов в терминологии, например: хамар 'нос' - хамар 'топ. холм, возвышенность, курган', тоориог 'ермолка (головной убор)' - тоориог 'бот. цветочная чашечка' и т. д. [Пюрбеев 1984: 46].

Э. Ч. Бардаев в своем труде «Современный калмыцкий язык. Лексикология» [Бардаев 1985] дает определение омонимов, раскрывает критерии разграничения омонимии и полисемии, подробно рассматривает типы и виды омонимов. Автор отмечает, что «слова, одинаковые по звучанию и написанию, но совершенно разные по значению, в лингвистике известны как омонимы. С многозначными словами не следует смешивать омонимию, при которой тождество звуковой формы создает впечатление, будто существует и тождество смысловое. При полисемии в известном смысле всегда сохраняется нечто общее между значениями. И оно постоянно, независимо от количества значений слова» [Бардаев 1985: 46-47].

П. А. Дарваев в работе «Келнә номин оршл» [Дарваев 2002], обращаясь к теме многозначности слова и омонимии, отмечает, что тема полисемии очень большая и многоплановая. По словам автора, принято отличать многозначные слова от омонимов, так как при полисемии все слова не теряют своего смыслового единства, хотя, наряду с этим, встречаются случаи перехода многозначных слов в разряд омонимов. П. А. Дарваев также различает собственно омонимы, грамматические и фонетические омонимы [Дарваев 2002: 16-18].

В статье В. Н. Мушаева и С. Н. Абдуллаева «Об изучении синтаксических омонимов (на материале монгольских и тюркских языков)» дается определение омонимии и ее разновидностей, рассматривается типология синтаксических омонимов, определяются способы образования и пути развития 
омонимичных конструкций [Мушаев, Абдуллаев 2017: 109-114].

В калмыцком языкознании вопрос о разграничении омонимов и лексико-семантических вариантов многозначного слова не был предметом специального лингвистического исследования и считается открытым на сегодняшний день, а малочисленные работы по омонимии калмыцкого языка не могут дать полную картину по данной теме. Таким образом, необходимо рассмотреть лексемы с омонимичными отношениями, то есть обследовать функциональный аспект омонимии. Поэтому необходимо провести разграничение между грамматическими, лексическими омонимами, возникшими путем семантической деривации. Комплексное лингвистическое исследование позволит выявить все новые и специфические сведения о взаимодействии лексики, грамматики, словообразования при возникновении омонимии между лексическими единицами языка. Безусловно, результаты настоящего исследования могут внести определенный вклад в изучение омонимии как лексической категории, что открывает новые пути в изучении лексико-семантической структуры слова в калмыцком языке, а также дать возможность проследить частные и общие моменты в формировании разных групп омонимов и открыть новые перспективы их изучения.

Источниковой базой для данного исследования послужил материал, собранный сплошной выборкой омонимов из калмыцко-русского словаря под редакцией Б. Д. Муниева [Калмыцко-русский словарь 1977] и картотеки, составленной путем выборки фактического материала из произведений калмыцкой художественной литературы, устного народного творчества и периодической печати. В работе также использовался ряд других словарей [Краткий русско-калмыцкий 1969; Манджикова 2002; Пюрбеев 1971].

В некоторых лингвистических работах омонимами считаются слова, совершенно одинаковые по произношению и написанию, но отличающиеся своими различными значениями. При этом к разряду лексических омонимов относят слова, принадлежащие к одной и той же части речи и отличающиеся друг от друга только лишь по своему лексическому значению. Однако при определении понятия «лексические омонимы» мы подразумеваем явление омонимии в широком плане, так как в калмыцком языке последние встречаются на разных уровнях языка. Например, наряду с омонимичными непроизводными и производными основами наличествуют омонимия словосочетаний и аффиксов и лексико-морфологические омонимы, также существующие как факт языка.

Исходя из этого, лексическими омонимами можно считать слова с различными значениями, идентичное звучание и графическое написание которых не обусловлено функциями словоизменительных и формообразующих аффиксов. Таким образом, при определении понятия «лексические омонимы», наряду с произношением, необходимо еще учесть и их одинаковое написание, так как омонимы, не совпадая с омографами по звучанию, отличаются от омофонов тождественностью внешней формы.

Возникновение омонимов связано с историей развития языка. В процессе развития словарного фонда калмыцкого языка образовались различные группы лексических омонимов. Отметим, что калмыцкому языку присуща многоплановость омонимичных связей между лексическими единицами, что во многом усложняет функциональный аспект исследования омонимии. Появившись как результат фонетических и семантических сдвигов, в современном состоянии языка они дифференцируются между собой по своим лексико-семантическим и грамматическим особенностям, поэтому при их классификации отправным пунктом являются их возникновение и дифференцирующие особенности в синхронном срезе.

Лексические омонимы являются самыми простыми из всех видов омонимов, которые целиком совпадают по звуковой и письменной форме. Например: hол 'река' - hол 'фитиль' — hол 'сердцевина' — hол 'главный, основной', тавг 'пятка' - тавг 'деревянная чашка', булг 'родник' - булг 'источник дохода' - булг 'гнойник уха' - булг 'белые пятна на ногах скота', $\theta$ 'дефект, изъян' - $\theta$ 'пудра' - $\theta$ 'обида' - $\theta$ 'умение, смекалка' - $\theta$ 'годы' - $\theta$ 'лес, чаща', өвр 'пазуха' - $ө в$ 'рог' - өвр 'мозоль' өвр 'борт' - өвр 'южный склон', оон 'сайгак (самец)' - оон 'тавро'.

В лексико-семантическом отношении все лексические омонимы, независимо от их происхождения, встречаются в двух видах: полные и неполные.

Полные лексические омонимы являются одной частью речи и совпадают друг с 
другом в своих основных грамматических формах, поэтому их называют полными лексическими омонимами, корневыми или собственно омонимами. Для разграничения омонимов, относящихся к одной и той же части речи, целесообразно пользоваться семантическими критериями, потому что настоящие омонимы отличаются друг от друга разностью обозначаемых ими значений. Например:

Им. п. hол 'река', 'фитиль', 'сердцевина'

Род. п. hольин 'реки', ‘фитиля’, 'сердцевины'

Дат. п. һолд 'реке', ‘фитилю’, ‘сердцевине'

Вин. п. hольг 'реку', ‘фитиля', ‘сердцевину';

Yзг 'буква', 'сторона, направление'

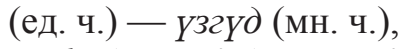

$x y p h н$ 'палец', 'ягненок' (ед. ч.) - хурһд (мн. ч.),

Үлгүр 'пословица', 'пример', 'выкройка' (ед. ч.) - үлгүрмүд (мн. ч.),

тавг 'пятка', 'деревянная чашка' (ед. ч.) — тавгуд (мн. ч.),

булг 'родник', 'источник дохода', 'гнойник уха', 'белые пятна на ногах скота' (ед. ч.) - булгуд (мн. ч.).

Интересно отметить, что последний ряд омонимов возник в ходе заимствования из тюркского языка. Образование данных лексем с участием заимствованных слов из других языков явилось результатом различных причин, основной из которых является подчинение иноязычного слова фонетическим законам калмыцкого литературного языка, например: булаг 'ключ, источник, родник' < др.-тюрк. булак 'источник, канал’ - булаг 'гнойник'.

Различают также и неполные омонимы, в таких случаях лексические единицы образуют омонимичные ряды с различными частями речи и совпадают лишь в части своих грамматических форм, к примеру, в им. п. ед. ч.: оошк 'легкие', 'розовый'; ора 'вершина', ‘поздно'; ач 'внук', 'заслуга'; $ө$ 'недра', 'заря’; болдг 'холм', 'справедливый, верный, но форму множественного числа принимают лишь первые слова: оошкс 'легкие', орас 'вершины', ачнр 'внуки', өрмүд 'недра', болдгуд 'холмы'. При определении данных омонимов, соотносительных с различными частями речи, нужно исходить из их принадлежности к разным лексико-грамматическим разрядам, так как основными отличительными свойствами таких омони- мов является несовпадение их грамматических форм.

Лексические омонимы по своему происхождению можно разделить на три группы.

В первую входят генетически не связанные, в языкознании известны под названием этимологические, исторические или гетерогенные омонимы. Данные этимологические омонимы образовались в результате полного совпадения по звучанию и написанию абсолютно разных слов. Например: өңзг 'цвет, окраска' - өн̧г 'друг, товарищ', өөн 'разум' — өөн 'год', сааль 'молоко разового удоя’ - сааль 'лук-самострел', саам 'удой' - саам 'период времени', изоохр 'севрюга' — цоохр 'пестрый', аньр 'гранат' — аньр 'звук, шум', бардмч 'хвастун' - бардмч 'бот. полынь обыкновенная', бәәр 'битва, бой, сражение' - бәәр 'лист (бумаги)'.

Ко второй группе относятся генетически связанные омонимы. Такие омонимы образовались в результате конверсии и распада полисемии, они именуются семантическими или гомогенными омонимами. Отличительной чертой генетически связанных омонимов является нетождественность их семантики, поэтому для определения их целесообразно использовать известные в науке синонимический, антонимический критерии и метод компонентного анализа определения омонимов. Например, орм 'место' - орм 'след', ооср 'веревка' ооср 'ошейник', ору 'гон' — ору 'половодье', ари 'можжевельник' - ари 'кипарис', архд 'большой бурдюк (для приготовления и хранения кумыса)' - архд 'высокий деревянный сосуд (для кумыса, айрана)', барх 'положить конец, довести до конца' - барx 'исчерпывать, израсходовать', бәрән 'арест, плен' - бәрән 'взятие, задержание', белчр 'устье реки, дельта реки' - белчр 'пастбище'. Неоднородность лексико-семантических и грамматических свойств генетически связанных омонимов свидетельствует о том, что критерии разграничения их не могут основываться на едином принципе, хотя при их возникновении имеется общность семантических изменений.

К третьей группе относятся омонимы, возникшие при участии словообразовательных аффиксов. Омонимы данной группы называются производными или словообразовательными. Например, тавта 'удобный, благоприятный' — maвma 'пятилетний' - тавта 'находящийся в готовности', 
цุолта 'имеющий звание, титул' - циолта 'имеющий свободное время', mamama 'открытый' - mamama 'запряженный (о лошади)'. Формообразующий аффикс создает условия для возникновения генетически неродственных омонимов.

Наряду с лексическими омонимами различают и грамматические омонимы или омоформы. К ним относятся слова, совпадающие по написанию и звучанию только в отдельных своих грамматических формах, но различающиеся по смыслу. Омоформы могут относиться к различным частям речи, сходным по форме только лишь в определенный совпавший момент речевого акта.

Необходимо заметить, что данные совпадения совершенно случайны, поэтому они непременно разрушаются при последующем изменении слова: прилагательные оошк 'розовый' и көрә 'мерзлый' являются неизменяемыми, а существительные оошк 'легкие' и көрә 'пила' склоняются по падежам и изменяются по числам. Примеры: ке 'красивый, нарядный' - ке 'делай', нар 'косточка, кубик' - нар 'иди сюда', сур 'кожаный ремешок' - сур 'спроси'.

Таким образом, данный тип включает омонимы «временные», непостоянной формы, существующие только лишь до последующего своего изменения. В результате изменения принципиально они различаются между собой и по звучанию, и по форме написания. Омоформы в калмыцком языке чаще всего представлены случайными совпадениями форм разных слов, реже случайными совпадениями разных грамматических форм одного и того же слова.

Одной из разновидностей омоформ выделяют конверсию, образующуюся в результате употребления одной части речи в функции другой. В результате конверсии образуются новые слова, разные части речи с различными лексическими значениями, но совпадающие по своей структуре и звучанию, таким образом, являющиеся омонимичными.

Отметим, что при переходе одной части речи в другую лексические единицы не меняют своего морфологического и фонетического облика, имеют нечто общее в своем значении и одинаково склоняются по падежам. Например: киитн Үвл 'холодная зима' (прил.) — киитн ирв 'наступил холод' (сущ.), зурһан күн 'шесть человек' (числ.) - тер мана зурhан 'те наши шестеро’ (сущ.), ноһан альчур 'зеленый пла- ток' - ноһан шавшна 'трава колышется', серүн өрүн 'прохладное утро' - серүн орв 'стало прохладно'.

Таким образом, данные лексемы представляют собой омонимы, относящиеся к различным частям речи, а не разные значения одного и того же слова. Необходимо отметить, что случаи конверсии в калмыцком языке широко распространены, среди них встречаются примеры синтаксической субстантивации, адъективации, адвербиализации. Окказиональные конверсионные отношения в лексическом составе калмыцкого языка возникают между знаменательными, знаменательными и служебными, а также самими служебными частями речи.

Различают омонимы, сходные по звучанию, но различные на письме - их называют фонетическими омонимами или омофонами. Данные омонимы образуются под влиянием фонетических закономерностей. К примеру, при переходе звонкого согласного в глухой: бордх 'откармливать' - бортх 'кожаный сосуд, кожаная фляга (для молочной водки)', хаmx 'сохнуть, высыхать' - хадx 'косить; забивать', бодь 'святость, совершенство' - боть 'том', бөгжс 'скоба, двойной крючок' - бөкч 'погас, потух (о свече)', богр 'жадный' - бокр 'неподвижный в суставах', бадрx 'расцветать' - батрх 'укрепляться, упрочиваться', $я \partial x$ 'уставать' — яmx 'ятха (музыкальный инструмент)'.

Различить согласные можно лишь при изменении форм данных слов: бордулх 'откармливать', хатах 'высушивать', хадx - хадур 'коса', бадрх - бадрул 'расцвет', богр - богрхг 'жадноватый', ядx - яду 'бедный, нищий'.

При сильной редукции гласных не первого слога размывается четкое различие согласных на конце слова, и образуются фонетические омонимы: ең 'каприз' - еңз 'ковш', сөң 'тост' - сөнуг 'один из пары', зун 'сто' - зун(0) 'лето'.

В связи с диалектными различиями в калмыцком литературном языке также образовались омофоны, различающиеся гласными на письме. Приведем примеры омофонов калмыцкого языка: $Y$ мсх (торг.) 'целовать' - өмсх (дерб.) 'одевать', хүв (торг.) 'доля' - хөв (дерб.) 'счастье', төгәх 'раздавать' - мүгәх 'заражать'.

Следует отметить, что некогда эти лексемы $х ү в / х ө в$ имели одно и то же значение 'счастье, доля', но впоследствии за каж- 
дым закрепилось лишь одно значение: $x_{Y 6}$ 'доля' - хөв 'счастье'.

В современном калмыцком языке встречаются слова с разным лексическим значением, имеющие что-то общее, но не тождественные в произношении. Данные лексические единицы принято называть паронимами, они очень близки к омофонам. Примеры: арсм 'спекуляция; нажива, барыш' - аршм 'аршин', күил 'успех, достижения' - күсл 'цель, мечта', сәкх 'посвящать, стеречь, оберегать, сторожить, караулить, охранять' - секх 'открывать', альчур 'платок' — арчул 'тряпка', цзасн 'снег' — ияаасн 'бумага', тосн 'масло' тоосн 'пыль', хол 'даль' - хоол 'горло, пищевод', не 'ладно, да, согласен' — нә 'надежда', тас 'совершенно, совсем' - таш 'камень', алс 'через' - али 'более ровная сторона альчика'.

Отметим, что при паронимии фонетическое совпадение приходится на начало слово или первый слог, разнится лишь конец слова. Данный вид омонимов чаще всего встречается в именах существительных и среди знаменательных частей речи.

В лексической системе калмыцкого языка встречаются и омографы - слова, одинаковые на письме, но различные по произношению. Данное языковое явление связано с тем, что редуцированные гласные калмыцкого языка перестали обозначаться на письме, в результате чего обнаруживаются омографы, например: бод 'крупный рогатый скот' - бод(э) 'думай, размышляй', һол 'река; фитиль; центр, середина; главный, основной' — hол(э) 'пренебрегай', тул 'таймень (рыба)' - тул(э) 'подопри', өр 'заря, рассвет' - өр(е) 'розжиг', хад (чолун) 'гранит' - хад(э) 'утес', хов (хоосн) 'совершенно пустой' — хов(э) 'сплетня', хәр 'посторонний, незнакомый; чужеземный; мелкий, неглубокий (о воде)' - хәр(е) 'возвращайся домой'.

В калмыцком языке, как и в любом другом, встречаются случаи совпадения с заимствованными словами из других языков, которые различаются лишь по месту ударения, например: калм. бор $(0)$ 'серый' — рус. бóp, калм. ад(0) 'бешенство' - рус. а́д, калм. $х о р(0)$ 'яд, отрава' — рус. хо́р, калм. azm 'скакун' - рус. а́кт, калм. ода́ 'сейчас' - рус. о́да, калм. $а x(0)$ 'брат' — рус. áx. Некоторые исследователи относят данное языковое явление к одной из разновидностей омонимии, которая возникла в ре- зультате случайного совпадения форм слов, абсолютно различных по значению и происхождению.

Следует отметить, что подобные совпадения звуковых форм неродственных языков не следует принимать за омонимы буквально, так как в данном случае мы имеем разные слова одинакового звучания совершенно случайно, а омонимы абсолютно несопоставимы в типологически разных языках. Данные лексические единицы не употребляются в одном и том же языке в качестве омонимов и не образуют омонимичных пар, каждые из них принадлежат лексике соответствующего языка и функционируют по законам того или иного языка и не имеют никакого отношения к лексике других языков. Примеры: калм. уульн на 'по эту сторону горы' - рус. на столе, на книгу; калм. олн то 'множественное число' — рус. то один, то другой, калм. улан киилг 'красная рубашка' — рус. эскадрон улан, калм. шар нарн 'желтое солнце' - рус. красный шар, калм. тур йовдг цุар 'выносливый вол' рус. третий $\boldsymbol{m y p}$.

Отметим, что различают еще один вид омонимов, образовавшихся в результате распада смысловых связей полисемичных слов, представляющих собой более сложные единицы в лексике калмыцкого языка в отличие от омонимов, появившихся в результате случайного совпадения. Вопрос об отнесении данных лексических единиц к омонимам в современной науке остается спорным, так как процесс распада полисемии происходит на протяжении длительного исторического времени и зачастую не всегда удается провести грань перехода многозначного слова в разряд омонимов. Критерии разграничения многозначных слов и омонимов субъективны. Основополагающими и наиболее приемлемыми для всех случаев разграничения многозначности и омонимии можно считать следующие критерии: обособленность производного значения слова от всех других его значений, его способность употребляться самостоятельно; осмысленность данных фактов большинством носителей того или иного языка.

Для выявления данного языкового явления необходимо рассматривать не только структурно-грамматические и семантические особенности, но и их этимологию. Приведем примеры: холвх 'умножать' холвx 'сцеплять; соединять, связывать; сты- 
ковать', харан 'подозрение' — харан 'силуэт', йовдл 'случай' - йовдл 'ход, ходьба'.

Таким образом, омонимия широко встречается в калмыцком языке, а основные типы омонимов несут ярко выраженный характер. Многообразие лексических единиц с омонимичными отношениями можно отнести к нескольким типологическим группам, сравнительно-сопоставительный анализ которых дает наиболее обобщенное и широкое представление об омонимии современного калмыцкого языка.

Наряду с этим в лингвистике существует мнение об отрицательном влиянии такого языкового явления, как омонимия, поскольку омонимы в определенных речевых ситуациях не могут быть поняты однозначно и мешают нормальному общению. Так, многие ученые считают омонимы нежелательными и предлагают разные их замены. К примеру, в калмыцком языке один из омонимов заменяют синонимом:

- xусм 'береза', 'накипь; пригорелая корка' - первое значение передается синонимом изаһан модн 'береза';

- шаль 'литовка', 'коса', второе значение передается лексемами хажс или хадур 'коса';

- цуох 'висок', 'ступа', второе значение передается словом суврһн 'ступа'.

Устранение омонимов также производится путем замены корня слова: бог 'сор, мусор' - буг 'сорняк', гемнх 'болеть' гемшәх 'обвинять', Үмсх 'целовать' 'одевать'.

Для различения омонимичных лексем также используется контекст. Например: Мани һол 'река Маныч' - зульн һол 'фитиль лампады' - hол зәнцг 'главное предложение', аавин көрә хури 'пила дедушки острая' — көрә һазр малтх 'копать мерзлую землю’, арвн тавна сар 'луна пятнадцатого числа' - Увлин һурвн сар 'три зимних месяца', байрин белг белглх 'дарить праздничный подарок' - далар белг бәрх 'гадать на лопаточной кости', толһан үсн 'волосы на голове' - Үкрин усн 'коровье молоко'.

Способы разграничения омонимов (использование синонимов, замена корня и контекст) нашли широкое применение в современном калмыцком языке, а лексемы из последних примеров, с помощью которых различают омонимы, вошли в обиход и активно используются в повседневной речи носителей. Функциональный аспект омонимии проявляется в случаях изменения лек- сических единиц в области лексики, грамматики, словообразования. Таким образом, проведенный качественный и количественный анализ единиц калмыцкого языка с омонимичными отношениями позволил определить виды и способы формирования омонимов в калмыцком языке.

Что касается омонимов, которые сформировались вследствие заимствования слов из других языков, то общеизвестно, что омонимы существуют и развиваются внутри каждого конкретного языка самостоятельно, независимо от каких-либо экстралингвистических факторов, и они несопоставимы в типологически разных языковых системах, в связи с чем данный лексический пласт представляет собой предмет отдельно взятого языка.

Изучение лексики того или иного языка предполагает выявление единиц в лексическом составе. Таким образом, всестороннее лингвистическое обследование омонимов калмыцкого языка является важным, а наряду с этим — и вопрос о создании «Словаря омонимов калмыцкого языка». Составление «Словаря омонимов калмыцкого языка» не только возможно с точки зрения теоретической, но и весьма актуально с точки зрения лексикологии и семасиологии, необходимость его давно уже назрела. Значение словаря омонимов калмыцкого языка для практической стилистики, для целей, которые определяются требованиями культуры речи, трудно переоценить.

В «Словаре» необходимо выявить различия, существующие между однозначными словами не только по эмоциональной окраске, но и в отношении смысловой сочетаемости. Для создания подобного словаря, прежде всего, необходимо иметь наиболее полный и очень точный список лексических единиц, четко описать все значения слов, так как без точного значения слова невозможно составить более менее удовлетворительный словарь омонимов того или иного национального языка.

В «Словаре омонимов калмыцкого языка» омонимические ряды не следует подбирать только лишь по одному основному значению многозначного слова. В омонимические ряды должны войти все значения слова, указанные в современных словарях, если они могут вступать в омонимические отношения с другими лексемами. Наряду с прочими значениями многозначного слова должны войти и переносные значения, ко- 
торые являются общеупотребительными. Серьезная и принципиальная постановка вопроса разграничения омонимии от полисемии все еще считается недостаточно разработанной и стоит остро, что не может не повлиять на работу при составлении словаря.

Необходимо отметить, что в «Словаре омонимов калмыцкого языка» нуждаются переводчики, работники местных СМИ, учителя и учащиеся школ, студенты и преподаватели высших и средних учебных заведений.

«Словарь омонимов калмыцкого языка» станет первой попыткой определить пути практического решения вопроса о выделении омонимических единиц в словарях. Он должен дать начальную базу для более широкого и детального обследования сложных проблем, касающихся семантики слова, определения ее границ.

Так, омонимия калмыцкого языка в синхронном плане не была еще предметом специального исследования. Настоящая работа является попыткой восполнить данный пробел в изучении лексического состава калмыцкого языка. Она нацелена на комплексное лингвистическое описание омонимов и связей между ними. Проведенный нами анализ показал, что в калмыцком языке омонимы образуются в результате разнообразных преобразований лексем. Возникают группы лексем с омонимичной формой, внутрисловные и межсловные связи которых поддаются разграничению лишь в языковом контексте.

Таким образом, данная работа является попыткой комплексного анализа способов формирования омонимов калмыцкого литературного языка, в которой приводятся сведения о типах и видах омонимов, затрагивается вопрос о создании «Словаря омонимов калмыцкого языка», рассматриваются проблемы и перспективы изучения омонимии калмыцкого языка.

\section{Благодарности}

Работа выполнена при финансовой поддержке РФФИ (проект № 16-04-00304).

\section{ЛИТЕРАТУРА / REFERENCES}

Виноградов 1977 - Виноградов В. В. Избранные труды. Лексикология и лексикография. M.: Наука, 1977. 312 с. [Vinogradov V. V. Izbrannye trudy. Leksikologiya i leksikografiya [Selected works. Lexicology and lexicography]. Moscow: Nauka, 1977. 312 p. (In Rus.)]
Бардаев 1981 - Бардаев Э. Ч. Вопросы лексикологии калмыцкого языка // Исследования по лексике калмыцкого языка. Элиста: КНИИ ИФЭ, 1981. С. 3-42. [Bardaev E. Ch. Issues of Kalmyk lexicology. Issledovaniya po leksike kalmytskogo yazyka [Studies of Kalmyk vocabulary]. Elista: Kalmyk Research Institute of History, Philology and Economics, 1981. Pp. 3-42. (In Rus.)]

Бардаев 1985 — Бардаев Э. Ч. Современный калмыцкий язык. Лексикология. Элиста: Калм. кн. изд-во, 1985. 152 с. [Bardaev E. Ch. Sovremennyy kalmytskiy yazyk. Leksikologiya [Modern Kalmyk: lexicology]. Elista: Kalm. Book Publ., 1985. 152 p. (In Rus.)]

Калмыцко-русский словарь 1977 Калмыцко-русский словарь / Бардаев Э. Ч., Джамбинова Р. А., Каляев А. Л., Кичиков А. Ш., Корсункиев Ц. К., Монраев М. У., Муниев Б. Д. (ред.), Павлов Д. А., Убушаев Н. Н. М.: Русский язык, 1977. 768 с. [Kalmytsko-russkiy slovar' [Kalmyk-Russian dictionary]. Muniev B. et al. (eds.). Moscow: Russkiy Yazyk, 1977. 768 p. (In Kalm. and Rus.)]

Бертагаев 1974 - Бертагаев T. А. Лексика современных монгольских литературных языков. М.: Наука,1974. 383 с. [Bertagaev T. A. Leksika sovremennykh mongol'skikh literaturnykh yazykov [Mongolic languages: contemporary literary lexis]. Moscow: Nauka,1974. 383 p. (In Rus.)]

Дарваев 2002 - Дарваев П. А. Келнә номин оршл. Элст: Хальмг дегтр һарһач, 2002. 302 x. [Darvaev P. A. Kelnä nomin orshl [Introduction to (Kalmyk) linguistics]. Elista: Kalm. Book Publ., 2002. 302 p. (In Kalm.)]

Краткий русско-калмыцкий 1969 - Краткий русско-калмыцкий словарь / И. К. Илишкин, Б. Д. Муниев. М.: Сов. энциклопедия, 1969. 357 c. [Kratkiy russko-kalmytskiy slovar' [A concise Russian-Kalmyk dictionary]. I. K. Ilishkin, B. D. Muniev (eds.). Moscow: Sov. Entsiklopediya, 1969. 357 p. (In Rus. and Kalm.)]

Колесников 1995 - Колесников Н. П. Словарь омонимов русского языка. М.: Феникс, 1995. 672 c. [Kolesnikov N. P. Slovar' omonimov russkogo yazyka [A homonymic dictionary of Russian]. Moscow: Feniks, 1995. 672 p. (In Rus.)]

Логачева 2008 - Логачева И. С. Теоретические основания исследования омонимии как языковой универсалии // Альманах современной науки и образования. Тамбов: Грамота, 2008. С.115-117. [Logacheva I. S. 
Homonymy as a linguistic universal: theoretical research grounds. Al'manakh sovremennoy nauki i obrazovaniya. Tambov: Gramota, 2008. Pp. 115-117. (In Rus.)]

Малаховский 1990 - Малаховский Л. В. Теория лексической и грамматической омонимии. Л.: Наука, 1990. 238 с. [Malakhovskiy L. V. Teoriya leksicheskoy $i$ grammaticheskoy omonimii [Theory of lexical and grammatical homonymy]. Leningrad: Nauka, 1990. 238 p. (In Rus.)]

Манджикова 2002 - Манджикова Б. Б. Толковый словарь калмыцкого языка. Элиста: АПП «Джангар», 2002. 86 с. [Mandzhikova B. B. Tolkovyy slovar' kalmytskogo yazyka [An explanatory dictionary of the Kalmyk language]. Elista: Dzhangar, 2002. 86 p. (In Rus.)]

Мушаев, Абдуллаев 2017 - Мушаев B. Н., Абдуллаев C. H. Об изучении синтаксических омонимов (на материале монгольских и тюркских языков) // Вестник Калмыцкого университета. 2017. № 4. С. 109-114. [Mushaev V. N., Abdullaev S. N. On the study of syntactic homonyms on the basis of texts in Mongol and Turkish languages.
Vestnik Kalmytskogo universiteta. 2017. No. 4. Pp. 109-114. (In Rus.)]

Павлов 1969 - Павлов Д. А. О развитии лексики калмыцкого языка за счет внутренних его ресурсов // Ученые записки КНИИЯЛИ. Элиста: КНИИЯЛИ, 1969. С. 127-155. [Pavlov D. A. Development of Kalmyk lexis through internal language resources. Uchenye zapiski KNIIYALI. Elista: Kalmyk Research Institute of Language, Literature and History, 1969. Pp. 127-155. (In Rus.)]

Пюрбеев 1971 - Пюрбеев Г. Ц. Краткий калмыцко-русский словарь глагольных фразеологизмов. Элиста: КНИИЯЛИ, 1971. 59 c. [Pyurbeev G. Ts. Kratkiy kalmytskorusskiy slovar' glagol'nykh frazeologizmov [A concise Kalmyk-Russian dictionary of verbal phraseological units]. Elista: Kalmyk Research Institute of Language, Literature and History, 1971. 59 p. (In Rus.)]

Пюрбеев 1984 - Пюрбеев Г. Ц. Современная монгольская терминология. М.: Наука, 1984. 119 c. [Pyurbeev G. Ts. Sovremennaya mongol'skaya terminologiya [Modern Mongolian terminology]. Moscow: Nauka, 1984. 119 p. (In Rus.)] 


\title{
Kalmyk Homonymic Studies and the Challenge of Compiling a Homonymic Dictionary Revisited
}

\author{
Vyacheslav N. Khoninov ${ }^{1}$
}

${ }^{1}$ Ph.D. in Philology (Cand. of Philological Sc.), Research Associate, Institute of Linguistics of the RAS (Build. 1, 1, Bolshoy Kislovsky Lane, Moscow, 125009, Russian Federation). ORCID: 00000001-8461-6213. E-mail: altngasn@rambler.ru

\begin{abstract}
Goals: The paper provides an overview of Kalmyk homonymic studies, determines criteria to differentiate between homonyms and polysemantic words, describes lexical and semantic ties between different variants of one word or different words, examines grammatical and word-forming homonymy. The work is a case study of lexical materials collected through continuous sampling of homonyms contained in the Kalmyk-Russian Dictionary by B. Muniev and the author's cardcatalogue compiled from literary writings, oral folklore texts, and periodicals.

Methods: The study conducts a qualitative and quantitative analysis of pairs of modern Kalmyk lexemes with diverse homonymic ties that proved helpful in identifying types (and kinds) of homonymy.

Results: The study revealed the types of homonyms as follows: lexical, grammatical, and phonetic ones.

Lexical homonyms can be etymologically divided into three groups.

Group 1 includes genetically unrelated homonyms, namely, etymological, historical, and heterogeneous ones. Such etymological homonyms appeared as results of full phonetic and scriptural matches of different words, e. g., өңъг 'color, pigment' - өңг 'friend, comrade', саам 'milk yield' саам 'period of time', цоохр 'starred sturgeon' — uоoхр 'variegated'.

Group 2 includes genetically related homonyms that have resulted from conversions and split polysemies; those are referred to as semantic of homogenous homonyms. For example, opм 'place' - орм 'trace, trail', ооср 'rope' — oоср 'dog-collar', opy 'estrus' - opy '(spring) flood'.

Group 3 includes homonyms that emerged with the aid of word-forming affixes, such homonyms being referred to as derivative ones. For example, maвma 'convenient, favorable' - maвma 'fiveyear-old' - maвma 'he who is ready (to act)'.

Grammatical homonyms, or homoforms, are words that coincide phonetically and scripturally only in separate grammatical forms but are semantically different, e.g., $\kappa e$ 'beautiful, elegant' — 'do', нар 'bone, cube' — нар 'Come here!', cyp 'leather bag' — cyp 'Ask!'.

Another kind of omoforms is conversion when a word of one part of speech functionally acts as that of another. For example, киитн үвл 'cold winter' (adj.) - киитн ирв 'cold has come' (noun), ноһан альчур 'green kerchief' — ноһан шавшна 'grass trembles'.

There are homonyms similar phonetically but differing scripturally, the latter referred to as homophones. For example, that is the case when a voiced consonant becomes a voiceless one: бордx 'fatten' — бортx 'leather vessel, leather flask (for milk vodka)', ядx 'get tired' — яmx 'yatkha (a musical instrument)'.

Dialectal differences in the Kalmyk literary language have also given rise to a number of homophones, such as YMcx (Torghut) 'kiss' — (Dorb.) 'happiness', пөгәx 'give' — - түгәx 'infect'.

The Kalmyk lexical system also contains omographs — words that are similar scripturally but differ phonetically, e.g., бод 'cattle' — бод(э) 'think, reflect', тул 'taimen (fisg)' — тул(э) 'Support!'.

There are a number of coincidences between Kalmyk and loan words that differ by location of stress only, e.g., Kalm. бор(0) 'grey' — Rus. бóp 'pinewood'; Kalm. ад(0) 'fury' — Rus. ád 'hell'; Kalm. xop (0) 'poison' — pyc. xóp 'choir'.

Conclusions: The analysis conducted shows that Kalmyk homonyms emerge through a variety of lexical transformations, grouped homonyms to be classified depending upon language contexts.

Thus, the work attempts to semantically describe formation means, types and patterns of homonyms in the Kalmyk literary language.

Keywords: Kalmyk language, lexis, homonyms, lexical homonyms, etymological homonyms,
\end{abstract} semantic meaning, polysemy, homoforms 